\title{
Ensuring the determinant of waqf in Indonesia: does religiosity matter?
}

\author{
Achmad Nurdany \\ Faculty of Economics and Business, Universitas Islam Negeri Sunan Kalijaga, Yogyakarta, Indonesia \\ E-mail: achmad.nurdany@uin-suka.ac.id
}

Keywords:
Waqf, Islamic land
endowment, religiosity.
DOI:
$\underline{\text { 10.20885/JEKI.vol5.iss1.art3 }}$

Keywords:

10.20885/JEKI.vol5.isstiat

\begin{abstract}
This paper examines the determinant of waqf (Islamic Endowment) in form of land in Indonesia. The study used cross-section data analysis from 33 Provinces provided by Ministry of Religious Affairs Republic of Indonesia in 2016. This paper proposed a model and developed a hypothesis that the total number of land waqf in Indonesia will be determined by the ratio of Muslims to total population, the number of mosques and the number of clerics. The results showed that the impact toward waqf varies among independent variables. The ratio of Muslims does not have any relation to the waqf even though the regression coefficient is positive. The number of mosques has a negative impact, while the positive relationship only found in the number of clerics. For that reason, some policy recommendations are also discussed.
\end{abstract}

\begin{abstract}
Abstrak
Tulisan ini menguji pengaruh waqf tanah wakaf Islam. Penulis menggunakan cross-section analisis dari 33 provinsi dari Kementrian Agama Republik Indonesia tahun 2016. Tulisan ini mengajukan sebuah model dan pengembangan hipotesis dengan jumlah tanah waqf di Indonesia akan diukur dengan jumlah penduduk Muslim, jumlah masjid dan jumlah ulama. Hasil pengujian menunjukkan hasil yang bervariasi terhadap pengaruh waqf. Rasio penduduk Muslim tidak berpengaruh terhadap waqf meskipun koefisiennya positif. Jumlah masjid memiliki pengaruh negatif, sedangkan jumlah ulama memiliki pengaruh positif. Sehingga beberapa rekomendasi kebijakan dibahas dalam tulisan ini.
\end{abstract}

\section{Introduction}

Indonesia has the largest Muslim populations in the world. Based on Pew Research Center, the country is a home for more than 205 million of Muslims, 88\% of total Indonesian population or 13\% of total Muslim population in the world. As a country with the biggest Muslim population, Indonesia has enormous potential for the growth of Islamic financial institution. Islamic banking, Islamic capital market, Islamic microfinance, and Islamic charity organization are some of the popular financial institution models.

The popularity of Islamic charity-based organization has recently grown in Muslim societies. The organization usually uses charity-based contract, i.e. zakah, waqf, and shadaqah. Literally, based on Indonesia Waqf Act 2004, waqf can be defined as a legal act of giving or separating some of the wealth, for the purpose of worship or public welfare, for a specified period of time or permanently. Today, there are approximately more than 435 thousand locations of waqf land with the total area of 4.3 million $\mathrm{m}^{2}$ in Indonesia. Of that number, 68 percent are certified while the rest are not.

Because of the nature of no-compensation contract between the grantor and the recipient, zakah, waqf, and shadaqah become some alternatives source of funding. Even waqf, especially cash waqf, now has been widely proposed as the source of funding for SMEs (Asmy \& Mohammed, 2013; Lahsasna, 2010), education (Aziz, Johari \& Yusof, 2013), microfinance (Masyita, 2012), economic development (Ibrahim, Amir \& Masron, 2013), poverty alleviation (Atika \& Fuadah, 2017) and health care services (Ahmed, 2013).

While the study on waqf has been well-researched, it is less likely known that the study is based on empirical analysis. Most of the waqf studies are the exploratory, preliminary, desk and library-based research, or qualitative analysis. The availability of data is the main factor that causes empirical research on waqf is very difficult to be done. The author is interested in conducting empirical research on waqf in Indonesia, a country with the largest Muslim population in the world, as the empirical research on waqf is very urgent. Fortunately, Indonesia has already published a complete data on waqf starting from 2013 forward.

This is the first paper of waqf discussion with the empirical analysis methods provided. This paper examines the determinant of waqf as an Islamic land endowment in Indonesia. The religiosity aspects are considered to be independent variables including the ratio of Muslims to the total population, the number of mosques and the number of clerics. 
Some pieces of literature that deal with the waqf discussion are indeed quite a lot, the classical books of ancient scholars have clearly explained about the chapter. However, the studies about waqf in recent academic journals are rather difficult to find, there are only a few from Behren-Abousef (1994) which discussed the adjustment of the Egyptians to the Ottoman Rules, in case of institution, waqf, and architecture. Furthermore, the article of (Dale \& Payind, 1999) also described waqf conditions in the past, namely Ahrari Waqf in Kabul in the year 1546 and the Mughul Naqsabandiyyah. Another well-known journal that often becomes scientific references about waqf is Kuran (2001) which defined waqf as a credible commitment device to give property owners in return for social services. Kuran mentioned that waqf is now being implemented not as it used to be. Waqf in the past can be used as a source of public goods funding, but now it is only financing the construction of building mosques, schools, libraries, monuments, and hospitals.

Recent study about waqf and its potential application has been carried out by Abdullah (2018). The paper attempts to contextualize the potential application of waqf toward sustainable development goals and the maqasid al-shariah. The author used a desk and library-based qualitative analysis. The result revealed that the seventeen goals in SDGs are comfortably matched with the long term objectives of maqasid al-shariah, including the use of waqf based instrument as a long-term development strategy. Waqf-based funding source can be optimized for the country development to fit the SDGs program. The waqf is also supporting the financial capacity to help Muslim in realizing the most urgent SGSs-oriented development in a timely manner.

Another study from Shabbir (2018) put an emphasize on classification and prioritization of waqf lands in Selangor Malaysia. The study purposed to determine the current status and development of lands waqf in the state of the country. A new model of classification and categorization of the lands waqf is also proposed. The method of the study is Analytic Hierarchy Process (AHP), and the result revealed that the waqf distribution varies among regions, it's based on the calculation of priority allocation which has been analyzed by researchers. The interesting statement of the author is that the waqf will be able to not only used as a form of worship, but also Muslim can use it as a vital instrument to increase wealth, alleviate poverty, and uplifting development.

Abu Talib et al. (2018) described that the importance of waqf in the society can be seen through its huge benefit. If it is linked to poverty, waqf is believed to be a cure for the disease. However, there is currently a lack of the waqf accounting system, and this problem is experienced by almost all countries in the world. Therefore, their research offered an explanatory study on reporting and accounting practices for waqf. The research was conducted on the recognition, measurement, and disclosure process in eleven state waqf institution in Malaysia. The result showed that each institution of waqf in Malaysia has different guidelines for conducting reports and accounting. The reason is that each individual waqf institution has different characteristics so that the results of the report and accounting become so dynamic. It is important to equalize the standard of accounting and reporting for the waqf institutions.

Regarding the accounting and reporting system of the waqf institution in Indonesia, the article written by Ihsan \& Mohamed Ibrahim (2011) has reviewed it. The paper examined two waqf institutions by collecting data in various method, i.e. interviews, document, reviews, and direct observations. The results of the study indicate that the process of reporting and managing waqf in different institutions varies. The cause of the difference is in the aspect of Islamically committed professional and academically qualified personnel. The first aspect is more important than the second in order to deal with more efficient waqf management institutions in Indonesia.

Another preliminary research has been conducted by Azizah et al. (2018). The study emphasized the benefit of waqf institutions toward parentless children in Malaysia. The study explained that all children in Malaysia are the best future assets of the nation, therefore protection against them needs to be done by all parties. But in reality, parentless children rarely get the protection. Through the library-based research method, the study then revealed the role of waqf in providing protection to the parentless children. It is believed to be a further avenue for future research. While Kachkar (2017) conducted research in the same field with a different method. The study utilized a qualitative method and revealed that the cash waqf can be proposed to develop a conceptual model of financing refugees. The model proposed in the study is the refugee micro entrepreneurs program development.

The possibility of using waqf, or cash waqf in an example, has been provided by Saad \& Anuar (2018) in their article. The main discussion is about the possibility of using cash waqf as a source of funding in order to support the microfinance programs. The purpose of the waqf based funding establishment is to ensure the direction of waqf institution development truly in line with the spirit of microfinance. Islamic microfinance institutions will always carry along with the needs of the poor, hence if using personal loan contracts (i.e. bay 'alinah) as a source of microfinance funding, the profit margin that must be paid by the poor is huge, it impairs them. Cash waqf contract, in this case, is totally worth it for the poor, it is very friendly for them, the use of waqf in microfinance will genuinely cater for the need of the poor, it can even create sustainable growth for the country. 
Moreover, Mikail et al. (2017) also consider the importance of using waqf in a micro-takaful model in Malaysia. The disintegration between zakat and waqf management as part of the Islamic economy in this microinsurance model can lead to a lack of effectiveness and sustainability of the institution management.

The study conducted by (Rizal \& Amin, 2017) is quite close to the research of mine. The paper examined the determinant term affecting people in giving cash waqf. The study used a questionnaires survey method on 264 Muslim respondents who have direct access to Islamic banking. The variables used in the study are perceived Ihsan, Islamic egalitarianism, and Islamic religiosity. The results show that all independent variables have a significant relationship toward cash waqf contributions. The practical implication of the research suggests that perceived Ihsan and equality will affect the religiosity sense of Muslim, so that will encourage the desire and willingness of Muslim to give such a cash waqf. Another study by Zeni \& Sapuan (2018) discusses the effect of waqf efficiency in Malaysia. Their research goal is to measure what factors can influence the efficiency of waqf. The research used a survey questionnaire method and analyzed with a Partial Least Square Structural Equation Model. The results showed that there is a significant positive relationship between waqf determinant and waqf efficiency. Practical implications of the research suggest that the findings are available to be adapted for the waqf institutions development.

The role of waqf in promoting socio-economic development has been reviewed by Mohamad (2018). He conducts a study on the role of waqf ahli or family waqf in the economy of the family, both for the aspect of security or sustainability. The result indicated that the waqf can prevent the family property from the fragmentation, and it can also ensure the financial planning of family becomes more sustainable.

The last thing to be noted in addition to the discussion of this research is the problems that arise in the process of waqf management in Indonesia, the solution, and the strategy that can be used to anticipate it. The imitation program from the neighboring country like Malaysia (Nur Khalidah, Noor Inayah, Mohamad, \& Mohd Rizal, 2014) is urgently needed to be implemented in Indonesia.

\section{Methodology}

\section{Proposed Model and Hypothesis Development}

Based on the literature review, the author proposes a model and develops a hypothesis that the total number of waqf in Indonesia will be determined by the ratio of Muslim to total population, the number of mosques and the number of clerics. This proposed model consists of three independent variables and a dependent variable. The three independent variables are the ratio of Muslim to total population, the number of mosques, and the number of clerics. While the dependent variable is the number of waqf land.

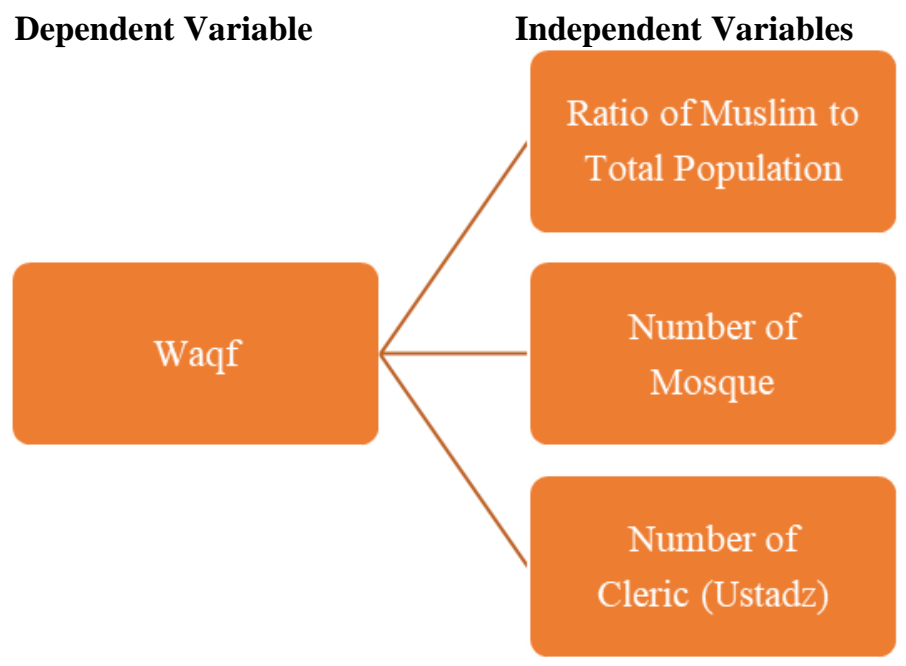

Figure 1. Hypothesis Development

The hypothesis is that the Muslim ratio to the total population is expected to have a positive influence on the amount of waqf. The positive impact is also ought to be found on the number of mosques as well as the number of clerics. This hypothesis can be explained because the more Muslims, the more mosques, and the more clerics, the greater the desire and awareness of the people to give a charity endowment such as a waqf. By that definition, the linear regression model is shown as follow:

$L W=\propto+\beta_{1} M R+\beta_{2} N M+\beta_{1} N C+e$ 


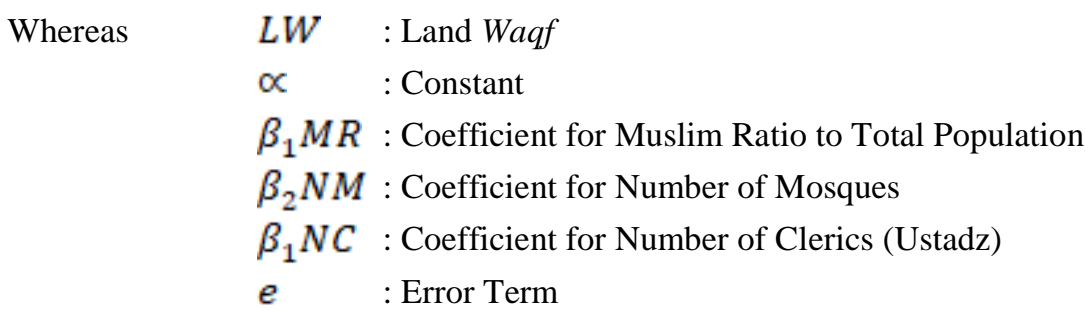

\section{Research Method}

This paper used cross-section data analysis from 33 Provinces in Indonesia. The data is purely secondary that was taken from the Ministry of Religious Affairs in 2016. The ministry report contains quantitative data which describe the ministry as a general, religious institution, religious educations, and religious affairs in Indonesia. Based on the variables of this study, the ministry report also provides a total number of waqf, Muslim population, total population, number of house of worship, and the number of clerics in each authorized religion.

In order to calculate the association between variables, the author used Ordinary Least Square Regression which is commonly implemented in the disciplines of economics. White Test is also used to measure the existence of heteroscedasticity, while Breusch-Godfrey Serial Correlation LM Test has been taken to detect the presence of autocorrelation. In order to determine whether there is a linear relationship between independent variables, a multicollinear test is also provided.

\section{Results and Analysis}

The common used OLS, Multicollinear Test, White Test, and Breusch-Godfrey Test had been done with the EViews 10 software and the estimation results are shown as follow:

Table 1: Ordinary Least Square Regression

\begin{tabular}{lrcrc}
\hline \multicolumn{1}{c}{ Variable } & Coefficient & \multicolumn{1}{c}{ Std. Error } & t-Statistic & Prob. \\
\hline \multicolumn{1}{c}{ C } & -22.3299 & 8.9867 & -2.4847 & 0.0190 \\
MR & 0.4617 & 0.4142 & 1.1145 & 0.2742 \\
\multicolumn{1}{c}{ LOG(NM) } & -12.6111 & 5.5939 & -2.2544 & 0.0319 \\
\multicolumn{1}{c}{ LOG(NC) } & 13.7530 & 5.6226 & 2.4459 & 0.0207 \\
\hline R-squared & 0.9250 Mean dependent var & 8.4608 \\
Adjusted R-squared & 0.9250 S.D. dependent var & 1.4257 \\
S.E. of regression & 0.4101 Akaike info criterion & 1.1684 \\
Sum squared resid & 4.8775 Schwarz criterion & 1.3498 \\
Log likelihood & -15.2793 Hannan-Quinn criter. & 1.2294 \\
F-statistic & 119.2491 Durbin-Watson stat & 1.2751 \\
Prob(F-statistic) & 0.0000 & \\
\hline
\end{tabular}

Table 1 summarizes the results of the study using the method that the author has previously explained. OLS regression is done in order to measure the influence of the independent variables MR, NM, and NC toward the dependent variable LW. While in order to meet the OLS assumption of multicollinearity, heteroscedasticity, and autocorrelation in this study, Multicollinearity Tes, White Test, and Breusch-Godfrey Test are implemented. The test of the OLS assumptions is done to ensure that the results of the study become a Best Linear and Unbiased Estimator (BLUE) regression. In a general conclusion, the research model is fairly good where from the $\mathrm{R}^{2}$ and Adjusted $\mathrm{R}^{2}$ values are quite high, namely 0.9250 and 0.9250 . Means that all the independent variables included in the study are able to give much impact towards the dependent variable by 91 percent, while the remaining nine percent are other influential variables which are not included in the research model.

Before going to the interpretation of the best model, the author has executed the OLS classical assumptions test with the results will be explained as follow. OLS assumption is carried out in order to obtain good and efficient regression results, namely Best Linear Unbiased Estimator. The OLS assumption test consists of three methods including multicollinearity, heteroscedasticity, and autocorrelation test. The multicollinearity test has been performed to measure the existence of the correlation between independent variables. The result revealed that there is a multicollinear problem but the author has carried out a log transformation variable process so that the correlation between the independent variables becomes smaller. The multicollinear problem 
in this study can be ignored as long as the problem of multicollinear does not alter the unbiased estimator of the regression model.

Table 2: Heteroscedasticity Test

\begin{tabular}{lll}
\hline F-statistic & 1.2997 Prob. F(8,24) & 0.2902 \\
Obs*R-squared & 9.9754 Prob. Chi-Square(8) & 0.2668 \\
Scaled explained SS & 9.0025 Prob. Chi-Square(8) & 0.3421 \\
\hline
\end{tabular}

The next OLS assumption test is a heteroscedasticity test. The author used White Test to measure the assumption of heteroscedasticity. Heteroscedasticity test is needed to ensure that the model has a constant variance. The model without a constant variance will be a linear, an unbiased, but not the best regression because of the minimum value of the variance cannot be achieved. The results showed that Obs*R-squared was 9.9754 which was greater than 0.05 and it means that the research model did not reveal a heteroscedasticity problem (see Table 2).

The autocorrelation test was done using the Breusch-Godfrey Serial Correlation LM Test. Its found that the research model had no autocorrelation problems. The problem of autocorrelation only arises when there is a correlation among error terms. In this study, the probability of Chi-Square in the Breusch-Godfrey Serial Correlation LM Test is 0.267 greater than 0.05 , which means that the autocorrelation problem does not exist as described in table 3.

Table 3: Autocorrelation Test

\begin{tabular}{lll}
\hline \multicolumn{3}{l}{ Breusch-Godfrey Serial Correlation LM Test: } \\
\hline F-statistic & 1.1722 Prob. F(2,27) & 0.3249 \\
Obs*R-squared & 2.6365 Prob. Chi-Square(2) & 0.2676 \\
\hline
\end{tabular}

For now, the OLS assumption test has been completely conducted, we would like to make an interpretation of the best model. After performing an ordinary least square regression, the final model of the study is shown as below:

$$
\log L W=-22.3299+0.4617 M R-12.6111 \log N M+13.7530 \log N C+e
$$

The interpretation of the regression for a constant value -22.3299 means that if all the independent variables are zero then the default value of the waqf is negative. In this case, it is appropriate for all independent variables such as Muslim its self, mosques, and clerics to be available in the society so that people want and aware to give charity such a waqf.

Another result for the independent variable MR (ratio of Muslim to total population) indicates that there is no significant relationship toward the dependent variable LW (land waqf) even though the direction is positive. The probability value 0.2742 with the positive variable coefficient are the proof of that result. This finding, however, is not in accordance with the expected hypothesis, which is Muslim ratio to total population will show a positive relationship toward waqf. The author guesses that the more Muslim will always be in line with the more waqf, meanwhile the results of this study revealed that there is no significant relationship between the two variables, even though the coefficient is positive.

The author presumes the reason behind the finding, that is annual growth of the Muslim population in Indonesia is higher than their awareness to pay such an endowment. This can be accepted because the waqf is one of the charity with a huge considerable value. The land is indeed expensive, not to say it is stingy, Muslim majority need to make a big sacrifice to get it, let alone to give it.

For the next independent variable NM (number of mosques), the result of the study is also not in line with the expected hypothesis. The number of mosques turned out to have a negative and significant effect on the waqf. Whereas in the hypothesis it was assumed that the more places of worship would escalate the willingness and awareness of the Muslim community to pay such an endowment. The variable probability 0.0319 means significant but the variable coefficient is negative, which is -12.6111 . This result needs to be clarified, even though the sign is significant but why the direct effect is oppositely connected. The author argues that the Muslim who wants to go to the mosque for doing prayer is still very low compared to those who prefer to stay calm at home. So, even though many mosques provided in the Muslim society, it cannot yet ensure that people's desire to give waqf is getting higher. Another fact, the impact can be negative because of the waqf then built into mosques, not for other productive businesses. 
The only variable meets the expectation of the hypothesis is the number of clerics. The research hypothesis stated that the number of clerics will have a positive and significant impact on waqf. Its mean that the more clerics give sermons for the goodness and importance of waqf, the higher the willingness and desire of the people to pay such an endowment. The results of this study support the hypothesis, it can be proven from the probability value of 0.0207 and the coefficient value of 13.7530. The author assumes that most of the clerics in Indonesia are able to influence Muslim society to do all the almighty God commands and stay away from His prohibitions. In this case, one of the God commands to His servant is paying a land waqf as a charity act.

This study concludes that the impact toward waqf varies among independent variables. The ratio of Muslim does not have any relation to the waqf even though the regression coefficient is positive, the number of mosques has a negative influence, while the only positive relationship found on the number of clerics. However, all the independent variables simultaneously and positively influence the dependent variable waqf in Indonesia. The value of F-Stat $(119,2491)$ and its probability $(0.0000)$ can be no doubt as evidence of this strong influence.

\section{Conclusion}

In general, the research model is fairly good as the $\mathrm{R}^{2}$ and Adjusted $\mathrm{R}^{2}$ values are pretty high, 0.9250 and 0.9250 . It means that all the independent variables included in the study are able to give big impact towards the dependent variable by 91 percent, while the remaining nine percent are other influential variables which are not included in the research model. However, it found a multicollinear problem which can be ignored as long as the problem does not alter the unbiased estimator of the regression model. In addition, the research model found neither heteroscedasticity nor autocorrelation problem.

Variable MR (ratio of Muslim to total population) indicates that there is no significant relationship toward the dependent variable LW (land waqf) even though the direction is positive. The reason behind the finding is that the annual growth of the Muslim population in Indonesia is higher than their awareness to pay such endowment. Variable NM (the number of mosques) turned out to have a negative and significant effect on the waqf. The impact can be negative because of the waqf given by Muslim then built into mosques, not for other productive businesses. The only variable meets the expectation of the hypothesis is Variable NC (the number of clerics) which has a positive impact on the LW (land waqf). The author assumes that most of the clerics in Indonesia are able to influence Muslim society to do the almighty God commands and stay away from His prohibitions. In this case, one of the God commands to His servant is paying a waqf as a charity act.

For that reason, some policy recommendations are also discussed. First, the government needs to put an emphasis on increasing the number of clerics rather than the number of mosques. Second, it is also necessary to improve their quality with the supporting programs, such as direct incentives on their performance improvement or monthly salary payment based on a certificate of capability recognition. Third, the government should manage or even regulate the waqf given by Muslim society to be used for any other productive-based business application.

\section{References}

Abdullah, M. (2018). Waqf, Sustainable Development Goals (SDGs) and maqasid al-shariah. International Journal of Social Economics, 45(1), 158-172. https://doi.org/10.1108/IJSE-10-2016-0295

Abu Talib, N. Y., Abdul, L. R., Aman, A., \& Palil, M. R. (2018). An exploratory study of accounting and reporting practice for waqf among State Islamic Religious Councils in Malaysia. International Journal of Islamic Thought, 13, 90-105. https://doi.org/10.24035/ijit.13.2018.009

Ahmed, U. (2013). Developing a waqf-based model for modern healthcare services in uganda. Unpublished doctoral dissertation, International Islamic University Malaysia, Malaysia.

Asmy, M., \& Mohammed, M. O. (2013). The challenges of micro enterprises in Malaysia and the prospect for integrated cash waqf microenterprise investment (ICWME-I) model. IIUM Repository, 1-18. https://doi.org/10.1016/j.applanim.2006.09.005

Atika, N., \& Fuadah. (2017). a Review on literature of waqf for poverty alleviation between 2006 - 2016. Library Philosophy and Practice, 1-31. http://digitalcommons.unl.edu/cgi/viewcontent.cgi?article=4202\&context=libphilprac

Aziz, M. R. A., Johari, F., \& Yusof, M. A. (2013). Cash waqf models for financing in education. 5th Islamic Economic System Conference: Proceedings of A Conference, May 2013, (835-842), Kuala Lumpur:Universiti Sains Islam Malaysia.

Azizah, Badruddin, \& Hidir, M. (2018). Charitable endowment (waqf) for the benefit of parentless children in 
Malaysia: a preliminary study. IIUM Law Journal, 26(2), 433-462.

Behren-Abousef, D. (1994). Egypt's adjustment to ottoman rule : institutions, waqf, and architecture in Cairo. Islamic History and Civilization, Studies and Text, 7.

Dale, S. F., \& Payind, A. (1999). The ahrārī waqf in Kābul in the year 1546 and the mughūl naqshbandiyyah. Journal of the American Oriental Society, 119(2), 218. https://doi.org/10.2307/606107

Huda, N., Rini, N., Mardoni, Y., Khudori, K., \& Anggraini, D. (2017). Problems, solutions, and strategy priority for waqf in Indonesia. Journal of Economic Cooperation and Development, 38(1), 29-54.

Ibrahim, H., Amir, A., \& Masron, T. A. (2013). Cash waqf: an innovative instrument for economic development. International Review of Social Sciences and Humanities, 6(1), 1-7. Retrieved from www.irssh.com

Ihsan, H., \& Mohamed Ibrahim, S. (2011). Waqf accounting and management in Indonesian waqf institutions: the cases of two waqf foundations. Humanomics, 27(4), 252-269. https://doi.org/10.1108/08288661111181305

Kachkar, O. A. (2017). Towards the establishment of cash waqf microfinance fund for refugees. ISRA International Journal of Islamic Finance, 9(1), 81-86. https://doi.org/10.1108/IJIF-07-2017-007

Kuran, T. (2001). The provision of public goods under Islamic law: origins, contributions, and limitations of the waqf system. Law \& Society Review, 35(4), 851. https://doi.org/10.2139/ssrn.276378

Lahsasna, A. (2010). The role of cash waqf in financing micro and medium sized enterprises (MMEs). In Seventh International Conference-The Tawhidi Epistemology: Zakat and Waqf Economy (pp. 97-118).

Masyita, D. (2012). Sustainable Islamic Microfinance Institutions In Indonesia: An Exploration Of Demand \& Supply Factors And The Role Of Waqf. Durham University. Retrieved from http://etheses.dur.ac.uk/5942/

Mikail, S. A., Ahmad, M. A. J., \& Adekunle, S. S. (2017). Utilisation of zakāh and waqf fund in micro-takāful models in Malaysia: an exploratory study. ISRA International Journal of Islamic Finance, 9(1), 100105. https://doi.org/10.1108/IJIF-07-2017-010

Mohamad, N. A. (2018). A study on the socio-economic roles of waqf ahli (Family waqf) in promoting family security and a sustainable family economy. IIUM Law Journal, 26(1), 141-160. Retrieved from http://irep.iium.edu.my/64571/

Nur Khalidah, D., Noor Inayah, Y., Mohamad, A. H., \& Mohd Rizal, P. (2014). Waqf (endowment) practice in Malaysian society. International Journal of Islamic Thought, 5, 56-61. https://doi.org/10.1038/nchem.701

Rizal, H., \& Amin, H. (2017). Perceived ihsan, Islamic egalitarianism and Islamic religiosity towards charitable giving of cash waqf. Journal of Islamic Marketing, 8(4), 669-685. https://doi.org/10.1108/JIMA-052015-0037

Saad, N. M., \& Anuar, A. (2018). Cash waqf and Islamic microfinance, untapped economic opportunity. Islam and Civilization renewal: the global financial Crisis (pp. 337-394).Malaysia: Pluto Journals

Shabbir, M. S. (2018). Classification and prioritization of waqf lands: a Selangor case. International Journal of Islamic and Middle Eastern Finance and Management, 11(1), 40-58. https://doi.org/10.1108/IMEFM02-2017-0038

Zeni, N. A. M., \& Sapuan, N. M. (2018). The determinants of waqf efficiency in Malaysia. Global Business and Management Research: An International Journal, 10(3), 1092-1106. 